\title{
RS1 wt Allele
}

National Cancer Institute

\section{Source}

National Cancer Institute. RS1 wt Allele. NCI Thesaurus. Code C75572.

Human RS1 wild-type allele is located within Xp22.2-p22.1 and is approximately $32 \mathrm{~kb}$ in length. This allele, which encodes retinoschisin protein, plays roles in retinal development and aging, and may have a role in cell-cell adhesion. Mutations in this gene are associated with X-linked juvenile retinoschisis. 